white plates. Among more than two hundred books listed for sale there is a number of items of scientific interest, including the editio princeps of Pliny's "Historia naturalis", printed at Venice in 1469 ; a first edition of Newton's "Principia" (another copy is offered in Catalogue 644); an exceptionally fine copy of Hooke's "Micrographia"; and the first illustrated edition of the "Hortus Sanitatis", printed at Mainz in 1491. Many interesting works are listed in Catalogues 644 and 650 , which contain 423 and 1,926 items, respectively.

Another catalogue of interest is that of Dr. E. Weil, c/o National Provincial Bank, 9 Market Place, London, N.W.11. This is No. 10, "From Alchemy to Chemistry and Pharmacology", and it includes also a section with sixty-nine works relating to the early history and development of photography. Among several works by or relating to Robert Boyle listed in this catalogue is Johann Seger von Weiden. feld's alchemical work "De Secretis Adeptorum" (London, 1684), in which the author made use of an unprinted manuscript by Boyle. Dr. Weil suggests that this manuscript, entitled "De Magisterio sive de investigatione secreti occulti Lullii", may be one of the Boyle manuscripts burned in 1688, of which, hitherto, no titles were known. This work, dedicated to Robert Boyle, will, it is stated, be described in Dr. J. F. Fulton's next addenda to his bibliography of Boyle.

\section{Food Calories}

THE Food and Agriculture Organisation of the United Nations has issued an interesting brochure entitled "Energy-Yielding Components of Food and Computation of Calorie Values" (from the Organisation, Washington, D.C.). This is the report of a Committee on Calorie Conversion Factors and Food Composition Tables, and contains much useful information. An appendix deals with organic acids as sources of available calories, and this includes a useful bibliography. The Committee considered the main causes of difference between estimates of energy-yielding components and of energy values, and concluded that the ideal procedure is separate determination of all the substances contained in food which contribute energy, combined with accurate assessment of their individual physiological values and their interrelationships. The question of the protein value of nitrogenous constituents is not completely resolved. Discussing carbohydrate values of foods, the Committee considers that at present the use of 'carbohydrate by difference' is justified, provided that its limitations are understood and appropriate procedures are used for deriving energy values. The value of the report cannot, however, be appreciated unless it is read.

\section{Earthquakes during the Last Quarter of 1947}

THE last quarter of 1947 opened with an earthquake on October 3 which was felt most strongly at San. tarem, caused some alarm in the working-class districts of Lisbon, and damaged many buildings in Lisbon, Cascaes and Estoril. There were about ten other strong earthquakes in October in various parts of the world, including the one felt strongly at Coroni in southern Greece on October 6, and another felt strongly and causing some property damage 40 miles south-west of Fairbanks in Alaska on October 16. The latter had an aftershock on October 20. During this month, thirty-eight small earthquakes and earth tremors were felt in New Zealand, the greatest being on October 13 from an epicentre at lat. $44 \cdot 2^{\circ} \mathrm{S}$., long. $169 \cdot 0^{\circ} \mathrm{E}$., felt over most of the South Island. November opened with an intense earthquake on November 1, 150 miles north-east of Lima in Peru. This caused considerable property damage and also was responsible for the deaths of at least fifty-three people. Strong aftershocks of the earthquake occurred on November 7 and 25. Of the fourteen other strong earthquakes during the month, that on November 23 in south-west Montana was felt in Montana and Idaho. In December, some thirteen strong shocks occurred, the European ones being felt on December 13 in the Pyrenees, on December 20 in the Tirol and on December 25 at Lago d'Iseo in Italy. Seismological reports have been received from Beograd (Yugoslavia), Durham, Kew, United States Coast and Geodetic Survey and Jesuit Seismological Association, Strasbourg, Stuttgart, Wellington (New Zealand) and Zurich and the Swiss observatories.

\section{International Conference on Sleeping Sickness}

At a conference convened jointly by the French, Belgian and British Colonial authorities and recently held at Brazzaville, French Congo, to which the Governments of Portuguese territories in Africa, of Southern Rhodesia and the Union of South Africa also sent delegates, arrangements were made for the uniform mapping of the whole of Africa south of the Sahara to show the incidence of trypanosomiasis in man and domestic animals and of the various species of tsetse fly which transmit it. It was also agreed to establish, at Brazzaville and Leopoldville, a joint bureau for the rapid exchange of information on methods of controlling the disease, and to set up in Europe a scientific committee on an international basis to supervise the organisation of research. These conclusions will now be forwarded to the Governments of all the African territories as recommendations for a concerted effort to control the disease and to work towards its gradual elimination.

\section{Society of Chemical Industry: Annual General Meeting}

TrE Society of Chemical Industry will hold its annual general meeting in Edinburgh during July 12-17. This is the first annual general meeting since the War to be held outside London, and the first since 1927 to be held in Edinburgh. The president of the Society, Dr. L. H. Lampitt, chief chemist and a director of Messrs. J. Lyons and Co., Ltd., will deliver his address on July 13. On July 14 there will be a lecture by Sir John Anderson, who has been awarded the Messel Medal for 1948 of the Society. The Lister Memorial Lecture will be given on July 15. This Lecture was founded to commemorate the influence of the work of the late Lord Lister on the pharm. aceutical industry in Edinburgh and was endowed in 1944 by two Edinburgh firms of drug and fine chemical manufactures, Messrs. J. F. Macfarlan and Co. and Messrs. T. and H. Smith, Ltd. The first lecturer, in 1944, was Sir Alexander Fleming. This year's Lecture will be devoted to biochemistry. A series of papers will be presented dealing with industrial chemical aspects of a number of the principal industries in the east of Scotland. They will describe some of the industrial research which has already been done in Scotland and will point to the possibilities for the future. In many cases the lectures will be followed by visits to the factories and installations of the various industries. Lectures will be given by Prof. S. Watson, principal of the East of Scotland 
College of Agriculture; Dr. G. A. Reay, of the Torry Research Station, Aberdeen; Mr. E. R. H. Edge, of Messrs. Alex. Pirie and Co., Aberdeen, on paper-making ; Prof. W. H. Melville, of the University of Aberdeen, on rubber; Dr. I. A. Preece, of the Heriot-Watt College, Edinburgh, on brewing; and Mr. H. Corteen, director of the British Jute Trade Research Association of Dundee, will speak on "Research Developments and Applications to Textile Industries in East Central Scotland". The meeting is being organised by the Edinburgh and East of Scotland Section of the Society, the honorary secretary of which is F. J. Bolton, 17 Wester Coates Avenue, Edinburgh 12.

\section{International Conference on Powder Metallurgy}

THE Steirmark Branch of the Association of Austrian Chemists is arranging an International Powder Metallurgy Conference to be held during July 12-16 in Graz. It is hoped, by lectures and discussions, to furnish a comprehensive picture of the position and problems of the scientific, industrial and economic aspects of powder metallurgy and allied subjects. The organising committee consists of Prof. G. Jantsch, Technische Hochschule, Graz; Dr. R. Kieffer, Metallwerk Plansee, Reutte, Tirol ; Prof. O. Kratky, Universität, Graz; Prof. G. F. Hüttig, Technische Hochschule, Graz. Further information can be obtained from Dr. C. Sykes, Brown - Firth Research Laboratories, Princess Street, Sheffield ; or Mr. M. Littman, Compound Electro Metals, Ltd., 42 Pall Mall, London, S.W.1.

\section{International Sericultural Congress}

The Seventh International Sericultural Congress will be held at Alès (Gard) in the Cevennes during June 7-13, and will be followed by an International Silk Congress at Lyons. The Sericultural Congress is being organised by the French National Institute of Agronomic Research; the president is Prof. R. Delmas, professor of sericulture in the École Nationale d'Agriculture, Montpellier, and the general secretary is M. Schenk, director of the Sericulture Research Station, Alès. The programme is being arranged in a number of sections covering scientific, economic and technical aspects of the subject. The Congress, which will mark the fiftieth anniversary of the research station at Alès, will be the first of so wide a scope since the Sixth International Sericultural Congress held in Paris during September 1878. Further particulars can be obtained from the Secrétariat-Général, Station de Recherche Séricoles, 28 Quai Boissier de Sauvages, Alès (Gard), France.

\section{Conference on Rheology and Textiles}

A Conference on "Rheology in the Textile Industries" has been arranged by the British Rheologists' Club in association with the Textile Institute, the Society of Dyers and Colourists, the Leeds area local sections of the Chemical Society and the Royal Institute of Chemistry, the Yorkshire Section of the Society of Chemical Industry and the Manchester and District Branch of the Institute of Physics, and will be held during March 19-20 in the Department of Textile Industries, University of Leeds. Further particulars can be obtained from Prof. J. B. Speakman, University, Leeds 2, or the honorary secretary of the British Rheologists' Club, Dr. E. W. J. Mardles, Royal Aircraft Establishment, Farnborough, Hampshire.

\section{Announcements}

AT a recent ceremony at the Royal Netherlands Embassy, London, the Netherlands Ambassador presented the insignia of Commander in the Order of Orange-Nassau (Civilian Division) in recognition of services rendered to the Netherlands during the War to the following, among others : Sir George Beharrell, chairman of the Dunlop Rubber Co., Ltd. ; Sir Jack Drummond, sometime scientific adviser to the Ministry of Food; Dr. John Hammond, reader in agricultural physiology, University of Cambridge; Sir Raymond Streat, chairman of the Cotton Board.

THE following appointments in the University of Leeds have been announced: Prof. H. S. Ruse, professor of pure mathematics, to be head of the Department of Mathematics on the retirement of Prof. S. Brodetsky at the end of the present session; Prof. T. G. Cowling, professor of mathematics at the University College of North Wales, Bangor, to be professor of applied mathematics from October 1 ; Dr. N. H. Hartshorme, to be lecturer in chemical microscopy.

THe following appointments in the University of Sheffield have been announced: Dr. A. J. Gould, senior lecturer in the Department of Glass Tech. nology ; Dr. J. S. D. Bacon, lecturer in biochemistry ; R. E. Davies, honorary lecturer in biochemistry; A. Jordan, honorary lecturer in elinical biochemistry.

A sxmposrum on "Combustion and Flame and Explosion Phenomena" will be held at the University of Wisconsin during September 7-11. Papers will be presented on fundamental and theoretical aspects of combustion, technical research, combustion prob. lems in jet propulsion, special fuels, etc. It is hoped to publish all the papers together within a few months of the meeting. Particulars can be obtained from Prof. Joseph O. Hirschfelder, University of Wisconsin, or from Dr. Bernard Lewis, U.S. Bureau of Mines, Pittsburgh 13, Pennsylvania.

THE Faraday Society is arranging one of its General Discussions, which will be held in the Department of Physies, University College, Southampton, during March 31-April 2. The subject will be "The Interaction of Water and Porous Materials", and the papers have been divided into four groups : (1) Funda. mental Aspects ; (2) Botanical Aspects : Mechanism of Movement of Solutions in Plants ; (3) Zoological Aspects: Water-Protecting Properties of Cuticles; and (4) Permeability to Water and Water Vapour of Textiles and other Fibrous Materials. Papers will be issued in advance of the meeting and taken as read. Further particulars can be obtained from the Faraday Society, 6 Gray's Inn Square, London, W.C.1.

The British Iron and Steel Research Association has now obtained a licence for erecting limited accommodation of temporary construction on a site at Meadow Street in Sheffield. At the present time the Association's investigations at Sheffield are divided between the Applied Science Department of the University of Sheffield (where there is an experimental rolling mill), the works of Arthur Lee and Sons, Ltd. (where there is a prototype backpull wire drawing machine), and elsewhere. The intention is ultimately to create a permanent building in which rolling, drawing and other similar researches will be centralized. 